\title{
Pelatihan Pembuatan Alat Peraga Digital Bagi Guru Paud dalam Upaya Meningkatkan Profesionalisme Guru
}

\author{
Training for the Making of Digital Devices for Paud Teachers in Efforts to Improve \\ Teacher Professionalism \\ Yopi Nisa Febianti ${ }^{1}$, Dian Permana Putri ${ }^{2}$, Utut Kurniati ${ }^{3}$ \\ ${ }^{1}$ Program Studi Pendidikan Ekonomi, Fakultas Keguruan dan Ilmu Pendidikan, Universitas Swadaya \\ Gunung Jati, Indonesia \\ ${ }^{2}$ Program Studi Pendidikan Matematika, Fakultas Keguruan dan Ilmu Pendidikan, Universitas Swadaya \\ Gunung Jati, Indonesia \\ ${ }^{3}$ Program Studi Pendidikan Bahasa Inggris, Fakultas Keguruan dan Ilmu Pendidikan, Universitas \\ Swadaya Gunung Jati, Indonesia \\ E-mail: $\underline{{ }^{1} \text { taniabekker@yahoo.com }}$
}

\begin{abstract}
Abstrak
Guru dapat meningkatkan prestasi kerja kependidikannya, yaitu kualitas anak didik, baik dari segi psikis maupun mental spiritual. Tujuannya, ialah: (1) Meningkatkan pengetahuan/pemahaman kepada guru PAUD mengenai alat peraga, manfaat, tujuan, dan kegunaan alat peraga; (2) Memperkenalkan bentuk dan pembuatan alat peraga kepada guru PAUD untuk menambah wawasan dan keterampilan; dan (3) Menanamkan sikap profesionalitas dalam mengajar peserta didik terkait pedagogic knowledge. Kegiatan ini dilaksanakan pelatihan pembuatan alat peraga digital untuk menunjang kompetensi pedagogik dalam rangka meningkatkan keprofesionalan guru. Hasilnya, kegiatan penyuluhan dan pelatihan ini sangat bermanfaat bagi semua peserta; $96,2 \%$ peserta memahami pemaparan materi; dan 92,3\% peserta telah mampu mengaplikasikan alat peraga digital.
\end{abstract}

Kata kunci-Alat peraga digital, guru, pedagogik, profesional.

\begin{abstract}
Teachers can improve their educational work performance, namely the quality of their students, both psychologically and mentally and spiritually. The objectives are: (1) Increasing knowledge / understanding of PAUD teachers regarding teaching aids, benefits, purposes, and uses of teaching aids; (2) Introducing the form and making of teaching aids to PAUD teachers to add insight and skills; and (3) Instilling a professional attitude in teaching students related to pedagogic knowledge. This activity is carried out by training in making digital teaching aids to support pedagogical competence in order to improve teacher professionalism. As a result, this extension and training activity was very beneficial for all participants; $96.2 \%$ of participants understood the material exposure; and $92.3 \%$ of participants have been able to apply digital props.
\end{abstract}

Keyword - digital props, teacher, pedagogic, professional.

\section{PENDAHULUAN}

Guru sebagai salah satu komponen pendidik di Indonesia memegang peranan yang penting dalam rangka mengemban tugas nasional, yaitu mencerdaskan kehidupan bangsa. Guru sebagai ujung tombak keberhasilan dalam rangka membentuk generasi penerus bangsa yang berkualitas harus memiliki kemampuan dan sikap profesional yang tinggi, sehingga dapat bekerja dengan sungguh-sungguh dalam mendidik siswanya agar lebih berkualitas. Oleh karena itu, guru diharapkan dapat meningkatkan prestasi kerja kependidikannya, yaitu kualitas anak didik, baik dari segi psikis maupun mental spiritual. Terbentuknya kemampuan dan sikap profesional guru-guru memang tidak mudah, belum tentu terbentuknya kemampuan profesional guru akan sekaligus terbentuk pula sikap profesionalnya, karena banyak faktor yang menentukannya. Meskipun guru telah terdidik di bidang kependidikan, belum tentu secara 
otomatis terbentuk pula kemampuan dan sikap profesional ini. Peningkatan profesionalisme guru sudah sewajarnya dilakukan, tidak hanya oleh pemerintah tapi dari diri guru itu sendiri juga harus punya kemauan dan upaya yang keras untuk dapat lebih professional, sehingga tujuan pendidikan nasional dapat tercapai seperti yang tercantum dalam Undang-undang Guru dan Dosen yang dijelaskan bahwa, guru adalah pendidik profesional dengan tugas utama mendidik, mengajar, membimbing, mengarahkan, melatih, menilai dan mengevaluasi peserta didik pada jalur pendidikan formal, serta pada pendidikan dasar dan menengah, termasuk pendidikan anak usia dini (Shabir, 2015, p.221).

Menurut Mulyasa (2007) dalam Firmadani (2017, p.165), profesionalisme guru di Indonesia masih rendah, hal ini disebabkan karena belum adanya perubahan pola mengajar dari sistem konvensional ke sistem kompetensi, beban kerja guru yang tinggi, dan masih banyak guru yang belum melakukan penelitian tindakan kelas. Atas dasar itulah, standar kompetensi dan sertifikasi guru dibentuk agar benar-benar terbentuk guru yang profesional dan mempunyai kompetensi yang sesuai dalam mengajar. Seorang guru yang berijazah sarjana (S1) kependidikan belum tentu memperlihatkan kompetensi yang baik, seperti dapat mengajar dengan terampil. Oleh karenanya, pemerintah membuat UU No. 14 Tahun 2005 tentang Guru yang menyatakan guru profesional selain memiliki kualifikasi akademik minimal S1, juga harus memiliki empat kompetensi lain yaitu kompetensi pedagogik, kompetensi sosial, kompetensi profesional, dan kompetensi kepribadian (Shabir, 2015, p.229). Tanpa bermaksud mengabaikan salah satu kompetensi yang ada, di dalam kegiatan PKM ini hanya akan dilaksanakan kegiatan tentang kompetensi pedagogik dalam rangka meningkatkan keprofesionalan untuk guru-guru terkait mata pelajaran Tematik dengan berbantuan alat peraga.

Menurut Payong (2011, p.28) secara etimologis, kata pedagogik berasal dari kata Yunani yaitu Padeos dan Agogos (Padeos adalah anak dan Agogos yang berarti mengatur/membimbing). Oleh karena itu, pedagogik berarti membimbing/mengatur anak. Tugas membimbing ini melekat dalam tugas seorang pendidik dan orang tua. Ketika peran orang tua digantikan oleh seorang guru di sekolah maka guru tidak hanya sebagai pengajar yang mentransfer ilmu pengetahuan dan keterampilan kepada siswa, tetapi juga merupakan pendidik dan pembimbing yang membantu siswa untuk mengembangkan segala potensinya baik itu potensi akademik maupun non akademik. Dalam standar nasional pendidikan dijelaskan bahwa kompetensi pedagogik adalah kemampuan mengelola pembelajaran peserta didik yang meliputi pemahaman terhadap peserta didik, perancangan dan pelaksanaan pembelajaran, evaluasi hasil belajar, dan pengembangan peserta didik untuk mengaktualisasikan berbagai potensi yang dimilikinya (Kurniawan dan Astuti, 2017, p.2). Berdasarkan uraian di atas, tim PKM ingin meningkatkan kompetensi keprofesionalan pedagogik untuk guru PAUD Kota Cirebon. Dengan guru memiliki kompetensi pedagogik ini maka diharapkan tujuan pendidikan nasional dapat tercapai, tentunya dengan dukungan dari ketiga kompetensi lainnya. Berdasarkan Surat Edaran Mendikbud Nomor 4 Tahun 2020 tentang Pelaksanaan Pendidikan Dalam Masa Darurat Covid19 diperkuat dengan Surat Edaran Mendikbud Nomor 15 Tahun 2020 tentang Pedoman Penyelenggaraan Belajar Dari Rumah Dalam Masa Darurat Penyebaran Covid-19 (SE Mendikbud, 2020), maka pelaksanaan KBM dari rumah/pembelajaran jarak jauh menuntut siswa dan guru untuk terampil menguasai multiliterasi untuk mengefektifkan kegiatan pembelajaran yang maksimal.

Kendala yang dialami siswa, guru dan orang tua dalam kegiatan belajar mengajar online, yaitu penguasaan teknologi masih kurang, tambahan biaya kuota internet, pekerjaan tambahan untuk orang tua dalam membantu anak dalam belajar, komunikasi dan sosialisasi antar siswa, guru dan orang tua dikurangi dan jam kerja guru tidak terbatas karena mereka harus berkomunikasi dan berkoordinasi dengan orang tua, guru lain, dan kepala sekolah. Pandemik juga turut mempengaruhi psikologis guru. Guru dihadapkan dengan kebutuhan untuk beradaptasi dengan pengajaran online. Kompetensi digital guru dan peluang guru untuk mempelajari kompetensi digital, berperan penting dalam beradaptasi dengan pengajaran online.

PAUD Lebah Kecil memiliki 36 orang murid yang terdiri dari beragam usia dari 2-6 tahun. Sedangkan SDM guru terdiri dari 6 orang. Pada saat pandemi yang mengharuskan 
pembelajaran jarak jauh dengan online, guru mengalami kesulitan dalam mengisi pembelajaran. Walaupun para guru memiliki keterampilan mengajar yang baik, dan sering mengisi pembelajaran jarak jauh di televisi lokal, namun guru masih mengalami kesulitan dalam membuat alat peraga digital yang sesuai dengan karakter peserta didik. Maria Montessori (Suryana, 2014, p. 1.38) berpendapat bahwa anak usia 3-6 tahun adalah usia anak taman kanakkanak (preschool) yang merupakan periode sensitif atau masa peka anak, yaitu periode di mana suatu fungsi tertentu perlu dirangsang, diarahkan sehingga tidak terlambat perkembangannya. Pada usia taman kanak-kanak, anak berada pada periode pembentukan diri. Dengan dorongan ini, anak secara spontan berupaya mengembangkan dan membentuk dirinya melalui pemahaman terhadap lingkungan. Selain itu, juga anak berada pada masa sensitif, yaitu suatu masa yang ditandai dengan begitu tertariknya anak terhadap suatu objek atau karakteristik tertentu dan cenderung mengabaikan objek-objek lain, sehingga guru perlu merancang media pembelajaran yang menarik dan merangsang perkembangan anak usia dini. Salah satunya adalah membuat media pembelajaran digital yang sesuai dengan karakter anak usia dini. Alat peraga digital sangat diperlukan dalam masa pembelajaran daring, terutama untuk anak usia dini. Sesuai karakternya, anak usia dini lebih mudah belajar bila melalui pendekatan realistik dan melalui audio visual, sehingga pelatihan pembuatan alat peraga digital bagi guru sangat diperlukan, bukan hanya dapat meningkatkan kualitas pembelajaran, namun juga meningkatkan kompetensi pedagogik dan profesionalisme guru.

\section{METODE PELAKSANAAN}

Metode pendekatan yang digunakan untuk mengatasi permasalahan yng dihadapi mitra adalah dengan metode penjelasan, pelatihan dan pendampingan pembuatan media pembelajaran digital. Secara rinci kegiatan PKM dijelaskan sebagai berikut.

1. Diskusi antara tim PKM dengan mitra untuk memperoleh gambaran permasalahan yang dihadapi mitra, serta penentuan masalah prioritas yang akan dipecahkan dalam kegiatan PKM.

2. Koordinasi antara tim PKM, mitra dan narasumber untuk menentukan waktu pelaksanaan kegiatan, materi pelatihan dan jadwal kegiatan serta melakukan persiapan pelaksanaan kegiatan seperti pembelian alat dan bahan, penyiapan lokasi kegiatan.

3. Pelaksanaan kegiatan. pada tahap ini dilakukan :

a. Penjelasan terkait media pembelajaran khususnya alat peraga digital.

b. Pelaksanaan pembuatan alat peraga digital berbantuan MS Power Point.

c. Pendampingan dan implementasi alat peraga digital yang telah dibuat.

4. Partisipasi mitra dalam pelaksanaan kegiatan meliputi :

a. Para guru mengikuti jadwal kegiatan yang telah disusun.

b. Para guru membuat alat peraga digital.

c. Para Guru mengimplementasikan alat peraga digital yang telah dibuat.

5. Evaluasi. Pada tahapan ini dilakukan :

a. Membandingkan kompetensi mitra sebelum dan sesuadah pelaksanaan kegiatan pelatihan.

b. Membandingkan tingkat pengetahuan, kemampuan dan keterampilan mitra dalam membuat alat peraga digital berbantuan MS Power Point.

\section{HASIL DAN PEMBAHASAN}

Kegiatan pengabdian kepada masyarakat dimulai pada akhir bulan Februari 2021 diawali dengan kegiatan pendataan calon peserta melalui pendaftaran di google form, lalu pembuatan grup chat WhatsApp untuk kemudahan share informasi. Pada kegiatan ini, dilakukan wawancara dengan Ketua Himpaudi Kota Cirebon untuk menentukan prioritas masalah yang 
ingin diselesaikan bersama dengan tim PKM UGJ. Dalam wawancara ini ditemukan beberapa masalah, antara lain sebagai berikut.

1. Pemanfaatan media pembelajaran masih kurang maksimal. Guru PAUD belum membuat alat peraga digital yang membantu peserta didik memahami pembelajaran.

2. Masih ada anggapan dari guru PAUD bahwa, pembuatan alat peraga digital merupakan pekerjaan yang berat dan membutuhkan banyak biaya, padahal alat peraga digital dapat dibuat secara sederhana dengan sistem aplikasi yang mudah ditemukan.

3. Pembelajaran belum didukung dengan media yang tepat sesuai kebutuhan dan karakteristik peserta didik.

Pelaksanaan kegiatan pendampingan dan penyuluhan alat peraga digital berlangsung pada hari Sabtu tanggal 27 Februari 2021 pada pukul 09.45 sampai dengan 12.30 WIB. Pada kegiatan ini dilakukan penyuluhan secara daring melalui Zoom Meeting, para peserta menyimak dari rumah masing-masing, sedangkan tim pelaksana PKM berada di rumah salah satu anggota tim PKM. Zoom Meeting dipilih karena para peserta telah terbiasa melakukan kegiatan pembelajaran daring melalui media tersebut. Adapun, tahapan kegiatan dimulai dengan sesi penjelasan tentang alat peraga digital pada anak usia dini. Pada tahap ini, pemateri menjelaskan dengan membagikan MS. Powerpoint beserta referensi pendukung (artikel) melalui Zoom Meeting. Dijelaskan bahwa alat peraga digital dipilih, karena: (1) Alat peraga digital paling diminati di semua jenjang pendidikan; (2) Sudah saatnya seorang guru mengikuti perkembangan teknologi; dan (3) Sekarang adalah zaman teknologi digital. Sebagai seorang pendidik, guru harus terus meningkatkan kemampuan profesionalnya, yaitu: (1) Kreatif dalam menyajikan pelajaran yang merangsang dan menantang; (2) Dapat menumbuhkan motivasi belajar peserta didik, dan (3) Memberikan penguatan atau reinforcement adalah suatu tindakan yang perlu dilakukan, serta pemberian umpan balik. Manfaat alat peraga digital adalah: (1) Proses pembelajaran menjadi lebih interaktif; (2) Proses pembelajaran menjadi lebih menarik; (3) Waktu yang lebih efesien; (4) Meningkatnya kualitas belajar; (5) Proses pembelajaran dapat terjadi dimana saja dan kapan saja; dan (6) Peran guru menjadi lebih kreatif dan produktif. Dijelaskan pula bahwa ada beberapa kriteria yang perlu dipertimbangkan guru dalam memilih alat peraga digital, yaitu: (1) Ketepatan alat peraga digital dengan tujuan pengajaran; (2) Dukungan terhadap isi bahan pelajaran; (3) Kemudahan memperoleh alat peraga digital; (4) Keterampilan guru dalam menggunakan alat peraga digital yang dipilih; (5) Tersedia waktu untuk menggunakan alat peraga digital yang dipilih; dan (6) Alat peraga digital yang dipilih sesuai dengan taraf berpikir anak. Setelah para peserta diberikan kesempatan untuk menyimak penyuluhan tersebut kemudian dilanjutkan dengan kegiatan pelatihan dan pendampingan, juga sesi tanya jawab. Pada kegiatan ini, para peserta mencoba membuat alat peraga digital dari aplikasi yang mudah digunakan, yaitu Kinemaster yang terus didampingi secara intensif oleh tim PKM. Saat kegiatan tersebut, tim PKM membagikan tutorial Kinemaster di Zoom Meeting, sehingga kegiatan pelatihan tersebut berjalan efektif. Para peserta juga terus aktif bertanya mengenai pembuatan materi pelajaran berupa video dari aplikasi Kinemaster tersebut. Setelah itu, para peserta diberikan angket respon mengenai pelatihan pembuatan alat peraga digital yang telah dilakukan. Sejumlah 78 peserta aktif mengisi angket respon tersebut. Selanjutnya, pada penutup diinformasikan bahwa sertifikat pelatihan akan dikirimkan pada email masing-masing peserta yang dituliskan saat pendaftaran di google form. Berikut adalah Tabel 1. jadwal dan susunan acara PKM.

Tabel 1. Jadwal dan Susunan Acara PKM

\begin{tabular}{|c|c|c|c|}
\hline Pukul & Durasi Waktu & Kegiatan & Pemateri \\
\hline 09.45 & 15 menit & $\begin{array}{l}\text { Peserta memasuki ruang } \\
\text { chat WhatsApp yang telah } \\
\text { dishare link Zoom Meeting } \\
\text { nya. }\end{array}$ & Tim pelaksana PKM. \\
\hline 10.00 & 10 menit & $\frac{\text { Pembukaan }}{\text { Perkenalan tim PKM oleh }}$ & Tim pelaksana PKM. \\
\hline
\end{tabular}

JAMU: Jurnal Abdi Masyarakat UMUS: $47-52$ 


\begin{tabular}{|c|c|c|c|}
\hline Pukul & Durasi Waktu & Kegiatan & Pemateri \\
\hline & & moderator. & \\
\hline 10.10 & 20 menit & $\begin{array}{l}\quad \text { Sambutan } \\
\text { Ketua Himpaudi Kota } \\
\text { Cirebon. }\end{array}$ & Ibu Nurzini Fazilet \\
\hline \multirow[t]{2}{*}{10.30} & 60 menit & $\underline{\text { Inti Acara }}$ & \\
\hline & & $\begin{array}{l}\text { Penyuluhan } \\
\text { Peserta menyimak } \\
\text { penjelasan tentang media } \\
\text { pembelajaran digital pada } \\
\text { anak usia dini } \\
\text { Pelatihan } \\
\text { Peserta membuat alat peraga } \\
\text { digital dengan aplikasi } \\
\text { Kinemaster. }\end{array}$ & Tim pelaksana PKM \\
\hline 11.30 & 45 menit & $\begin{array}{l}\text { Tanya jawab dan pengisian } \\
\text { angket. }\end{array}$ & Tim pelaksana $\mathrm{PKM}$ \\
\hline 12.15 & 15 menit & $\begin{array}{l}\quad \text { Penutup } \\
\text { Kesimpulan : merangkum } \\
\text { kegiatan inti acara }\end{array}$ & Tim pelaksana PKM \\
\hline & & $\begin{array}{l}\text { Memberikan informasi } \\
\text { mengenai sertifikat } \\
\text { pelatihan. }\end{array}$ & \\
\hline
\end{tabular}

\section{Dokumentasi}

Sedangkan, gambaran kegiatan pelatihan dan pendampingan pembuatan alat peraga digital dapat dilihat pada Gambar 1.

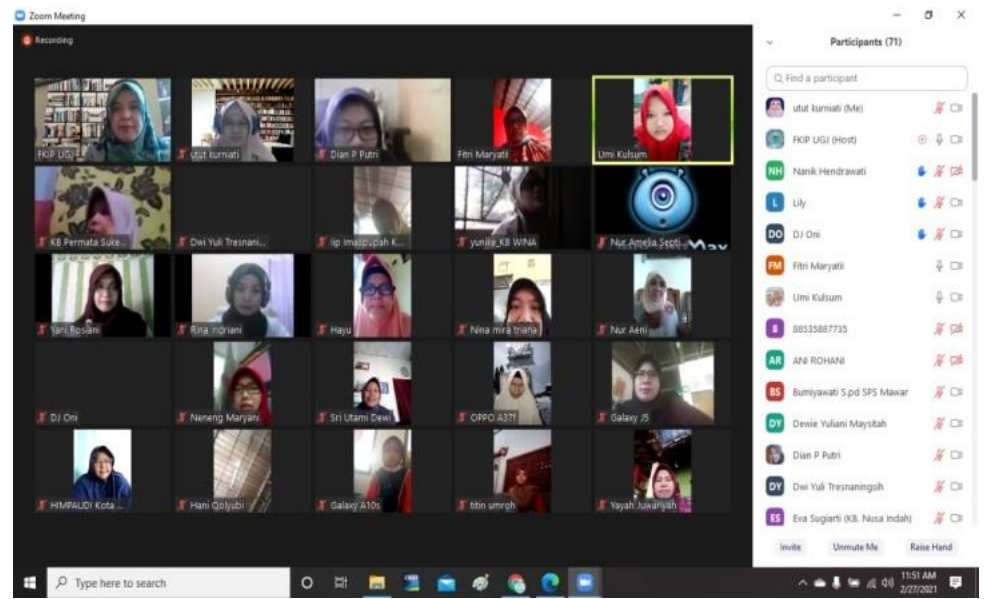

Gambar 1. Pelatihan dan Pendampingan Pembuatan Alat Peraga Digital

Kegiatan penyuluhan dan pelatihan guru PAUD mengenai pembuatan alat peraga digital, kemudian diukur dari respon peserta terhadap pelatihan pembuatan media pembelajaran dengan aplikasi Kinemaster menunjukkan respon yang sangat baik. Terbukti dari hasil angket yang menunjukkan bahwa kegiatan penyuluhan dan pelatihan ini sangat bermanfaat bagi semua 
peserta; 96,2\% peserta memahami pemaparan materi yang telah disampaikan; dan 92,3\% peserta telah mampu mengaplikasikan alat peraga digital dengan aplikasi Kinemaster. Peningkatan kemampuan profesional guru harus terus dilakukan agar guru dapat terus meningkatkan motivasi belajar anak didiknya. Semua cara yang terbaik dalam mendidik harus dilakukan agar dapat menyajikan pelajaran yang merangsang dan menantang anak didik. Selain dengan aplikasi Kinemaster, banyak aplikasi lain yang dapat digunakan untuk membuat alat peraga digital. Tetapi, pilihlah aplikasi yang mudah digunakan, agar proses pembuatan alat peraga dapat menghemat waktu dan efektif penyajiannya. Dan yang lebih penting lagi adalah anak didik kita mudah memahami materi pelajaran yang diberikan dengan alat peraga digital yang digunakan.

\section{KESIMPULAN}

Kegiatan penyuluhan dan pelatihan pembuatan alat peraga digital yang dilaksanakan pada hari Sabtu tanggal 27 Februari 2021 yang dihadiri oleh 78 peserta telah berjalan dengan lancar dan sukses. Diharapkan kegiatan ini mampu meningkatkan kemampuan profesional guru-guru PAUD dalam menyajikan pelajaran yang merangsang dan menantang anak didik dengan alat peraga digital yang mudah dibuat, juga murah biayanya.

\section{UCAPAN TERIMA KASIH}

Diucapkan terima kasih kepada Lembaga Pengabdian Masyarakat (LPM) Universitas Swadaya Gunung Jati, sehingga pelaksanaan kegiatan pengabdian ini berjalan dengan baik dan lancar.

\section{DAFTAR PUSTAKA}

Firmadani, Fifit. (2017). Strategi Pengembangan Profesionalisme Guru. Conference on Language and Language Teaching (CLLT). https://semnas.untidar.ac.id/wpcontent/uploads/2018/02/page-165-169-fifit.pdf.

Kurniawan, Ade \& Andari Puji Astuti. (2017). Deskripsi Kompetensi Pedagogik Guru Dan Calon Guru Kimia SMA Muhammadiyah 1 Semarang. Seminar Nasional Pendidikan, Sains dan Teknologi Fakultas Matematika dan Ilmu Pengetahuan Alam Universitas Muhammadiyah Semarang. https://jurnal.unimus.ac.id/index.php/psn12012010/article/download/3032/2946.

Payong, Marselur R. (2011). Sertifikasi Profesi Guru Konsep Dasar, Problematika, Implementasinya. Jakarta Barat: Indeks.

SE Mendikbud: Pelaksanaan Kebijakan Pendidikan dalam Masa Darurat Penyebaran Covid19. (2020). Kementerian Pendidikan Dan Kebudayaan.

Shabir U, M. (2015). Kedudukan Guru Sebagai Pendidik: (Tugas dan Tanggung Jawab, Hak dan Kewajiban, dan Kompetensi Guru). Jurnal Auladuna, 2(2), 221-232. http://journal.uin-alauddin.ac.id/index.php/auladuna/article/download/878/848.

Suryana, Dadan. (2014). Dasar-dasar Pendidikan TK: Hakikat Anak Usia Dini. http://repository.ut.ac.id/4697/1/PAUD4107-M1.pdf. 